\title{
Using dendrogeomorphology in research on a slope deformation in Běleč, Czech-Moravian Highland (Czech Republic)
}

\author{
DANIEL ŽÍŽALA ${ }^{1,2}$, JIŘÍ ZVELEBIL², VÍT VILÍMEK ${ }^{2}$ \\ ${ }^{1}$ Research Institute for Soil and Water Conservation Prague \\ ${ }^{2}$ Charles University in Prague, Faculty of Science, \\ Department of Physical Geography and Geoecology
}

\begin{abstract}
Research on the Běleč creeping slope deformation is a contribution to identification of the causes of a breakdown of the water-supply conduit of the Brno regional water-supply network and to ensuring its regular operation.

Field geomorphological mapping was used for the research and dendrogeomorphologic methods, especially the method of analysis of tree rings (eccentric tree rings, growth changes), were used for studying the slope failure dynamism. Slope movement activity in the years 1900-2007 was monitored with the help of 45 boring samples. The analysis of tree rings of common beech (Fagus sylvatica) samples did not prove continual movements over the whole extent of the deformation. The present activity is characterized only by local episodic movements of creeping character in the years 1947, 1975, 1993, 1997 a 2006. It was proved that the slope deformation did not have a direct impact on the breakdown of the water-supply conduit in 2005.
\end{abstract}

Key words: Deep-seated slope deformation, breakdown of the water-supply conduit, dendrogeomorphology, Czech-Moravian Highland

\section{Introduction}

Slope deformations belong to the most frequent forms of natural risk and hazards which may significantly damage objects, networks or communications. Considerable damages occur usually due to slope movements of catastrophic character that are often located in areas where the natural conditions increase the slopes susceptibility to landslides (as a specific lithologic structure, neotectonically active zones, and high mountain areas). Slope deformations of creeping character occurring in less susceptible areas are also risky for the human community.

Although the Běleč slope deformation is not a slope failure of catastrophic character, its presence and activity are related to the breakdown of the water-supply conduit of the Vír regional water-supply network supplying fresh water to nearly 150 municipalities in the district Brno-Venkov. Research on this failure thus helps not only to identify the interaction of physical-geographical and geological factors operating in this area, but also 
to ensure operation of the water-supply conduit. The principal question for ensuring regular operation of the water-supply conduit is thus the degree of activity of the slope deformation and the extent of its impact on the breakdown.

In the locality of the breakdown there is a portal of the BOV (Brno regional watersupply network) water-supply conduit leading through a gneiss massif via a pressure tunnel of $2.1 \mathrm{~m}$ diameter. On September 22, 2005, an extensive water flow (about 400 1/s) appeared at the left side of the portal house Běleč I. After drainage and reviewing it was found that the concrete lining in the upper portion of the profile was torn lengthwise at a distance of 70 to $85 \mathrm{~m}$ from the portal (Cigler and Follprecht 2007).

The breakdown could have occured due to several causes, classified by Pavlík (2005) into three groups, i.e. geological, constructional and operational. Among geological causes, he classes the existence of a fault zone bound to an adverse impact of underground water and to possible slope movements in the place of weakening of the massif. Constructional causes include the existence of construction joints and incomplete linking of steel reinforcement, badly prepared concrete and possibly insufficient filling of the space behind the lining with grouting. Operational causes of the breakdown could have occurred due to bad manipulation when closing the flow that could have resulted into an enormous increase of internal overpressure due to a water surge.

A series of research studies were done on the slope of interest after the breakdown; they are summed up in reports by Pavlík (2005) and Zvelebil et al. (2006). They include information obtained by structural-geological and engineering-geological mapping, by geophysical investigations and extensometric measurements.

In connection with the reviewing of the tunnel after the breakdown, georadar measurement was done in the whole length of the tunnel; it proved the existence of a significant fault zone in the area of the tunnel in many places of the massif (Cigler and Follprecht 2007).

Further georadar measurement was done in two profiles by Geodrill Company on the slope failure on the slope above the Běleč I portal. This georadar profiling found in the slope pronounced deep, mostly linearly elongated, deformation zones of gneisses (P. Dostál, oral communication). The places of extrusion of these zones correspond well in space to relief steps in the slope and thus support the theory that they are outcrops of slip surfaces (Zvelebil et al. 2006).

The measurement of crack systems and comparison of data from outcrops on the slope above the Běleč I portal with those from reference outcrops further proved that the rock massif is moving on metamorphic foliation surfaces (SSW orientation, inclination of $15-40^{\circ}$ ) to such an extent that significant break-offs along the main NW-SE and NE-SW oriented fissures appear (Hanžl and Buriánek 2006).

After evaluation of the geophysical research results and of data obtained by field structural-geological and engineering-geological mapping of the slope above the portal of the Běleč I water-supply conduit, the Czech Geological Survey’s (ČGS) hypothesis supports the existence of an extensive slope failure which, according to Zvelebil et al. (2006): “... has at least significantly contributed to the accidental breakdown of the tunnel's body." According to ČGS's estimations, this is a deep-seated gravitational slope failure with a long-term development and very slow creeping movements of a velocity of tenths of $\mathrm{mm}$ /year situated at altitudes up to $430-440 \mathrm{~m}$ (the valley bottom 
being at about $335 \mathrm{~m}$ a.s.1.) with its ground plan reaching minimally $180 \mathrm{~m}$ into the interior of the slope. According to this scenario, this is a long-term developing deformation with several development stages.

Pavlík (2005) states in his final report that slope movements could have contributed to the breakdown, but not as movements along the slide surface crossing the watersupply conduit segment, but by unloading a portion of the massif due to deflection of huge rock blocks.

Based on the above-sketched scenarios, the research was oriented mainly at the character and activity of the slope failure. The objective was to gather information on the dynamics of movements on the slope deformation in the recent past (about 100 years). Hence the main aim of this research is to determine exactly the periods of enhanced activity of slope deformation and, using geomorphological mapping, to evaluate its possible impact on the water-supply conduit breakdown in 2005 .

\section{Study area}

The Běleč creeping slope deformation is located in crystalline rocks of the Svratecká klenba Dome of the Moravicum (Bíteš orthogneiss) in the geomorphological unit Upper Svratka Highlands (Demek and Mackovčin 2006). Occurrence of larger creeping movements is not so frequent in this unit (Roštínský and Kirchner 2006). The slope deformation is bound to the SE slope of the Křeptovský Brook deep fault gap near Běleč in the district Brno-Venkov. The Křeptovský Brook valley mouths at about $1 \mathrm{~km}$ from the slope failure into a clinched meander of the Svratka River deep fault gap (Veselý 1983).

The deformation is situated in a steep slope inclined $34-35^{\circ}$ to the SE. There are up to several meters high rock outcrops (Bíteš orthogneisses) on the slope and the slope surface is covered by slope debris (Pavlík 2005).

The climate of the region is moist moderate with mild winters. The mean annual precipitation is $592 \mathrm{~mm}$ and the rainfall regime is characterized by a summer maximum. Nevertheless, the area is situated in the rain shadow of the Czech-Moravian Highland. The mean monthly temperatures vary between $-3{ }^{\circ} \mathrm{C}$ in January and $16{ }^{\circ} \mathrm{C}$ in July.

\section{Material and methods}

Field mapping was used during the research on the Běleč slope deformation. Dendrogeomorphological methods were used for research on the dynamics of the slope failure (recently and at the time of the water-supply conduit breakdown). A method of tree ring analysis of samples obtained using an increment corer, which is a relatively quick non-destructive research method, was used.

The term dendrogeomorphology as introduced by Alestalo (1971) denotes a dendrochronological method dealing with the response of trees to geomorphological processes. It provides data on the beginning, duration, amplitude or frequency of these processes. The method described already by Alestalo (1971) and Shroder (1980) is based on analysis of growth patterns of woody species, tree rings, shapes of trunks, branches and roots. 
Analysis of eccentric growth of tree rings and their growth suppression or abrupt growth was used in the research on the Běleč slope deformation.

The growth of eccentric tree rings is a response to an inclination of the tree due to instances of slope movements. The tree tends to regain an equilibrated position and the eccentric growth rings substitute concentric rings. For angiosperm trees, formation of tension wood is characteristic (on the opposite side of the inclination direction). There is typically an enhancement growth on the upslope tension wood side in contrast to normal and reducing growth in the opposite wood on the downslope side. This changes gets formed at least during the year following the initiating event. Deflection of a tree from its optimal position resulting from a similar event can therefore be exactly dated, usually in combination with geomorphological mapping (Gärtner et al. 2003; Heinrich and Gärtner 2008).

Growth suppression or abrupt growth of tree rings can also be a reaction to a slope movement and it can be easily interpreted from the growth curve of the tree (e.g. Carrara and O'Neill 2003; Holland 2008; Paolini et al. 2005, Van Den Eeckhaut et al. 2009). A growth suppression of tree rings occurs for instance due to deterioration of the root system as a result of a movement. On the contrary, abrupt growth can be caused by elimination of neighboring vegetation, i.e. by elimination of competing vegetation, which can be caused by slope movements (Holland 2008). Other causes such as fires, diseases, uprooting, economic activities or competitive struggle can be eliminated by inspection of the locality.

Selection of trees suited for dendrogeomorphologic research depends on the characteristics of the tree's stand rather than on biological characteristics. In practice, it is necessary to use the species growing on the site (Daňhelka 1999).

Evaluation of the dynamism of the Běleč slope failure based on tree rings series analysis was possible roughly for the period 1900-2007. The oldest boring reached the year 1861, but a sufficient amount of series was available only for the period after 1900 . As the samples were taken in summer 2008 and the last tree ring was not completely formed yet, the deformation's activity could be assessed to the year 2007. Forty-three samples were used for analysis. Samples from tree number 4 were too damaged to be used.

A $60 \mathrm{~cm}$ long Pressler increment borer was used for collecting samples. In total 45 samples from 21 trees were taken. In order to record the oldest events, common beeches (Fagus sylvatica) were used for analysis. Although there are only a few of them on the slope, they were the most vigorous (oldest) and manifested the highest marks of deformation (deflection from vertical position) and that is why they were analysed. In addition, beech is known as a straight grower, and has low sensitivity to light competition (Van Den Eeckhaut et al. 2009). The trees were more than 100 years old (see Fig. 1), but were not always bored into the center, hence some samples are shorter. Samples from 10 trees were taken on the actual slope deformation in the area of its presupposed delimitation. Sample-collection was made from trees with visible inclination. Six trees were selected in the neighborhood on the same slope in order to assess stability of this part of slope and to determine the extent of the failure. Three trees without visible bends in the trunk were also sampled in this area due to lack of tilting trees. In addition, increment cores were collected from four control trees outside the mentioned areas. These trees were adjacent to the slope deformation in area with 
surface slopes of less than $7^{\circ}$ with no indication of unstable bedrock. At least two samples were taken from each tree. One sample was collected perpendicularly on the contour line on the slope in the direction of the inclination on the downslope side (sample C), the second one perpendicularly to it (sample B) in the direction of the contour line. In the case of inclination of the tree in a direction other than along the gradient line or in the case of an opposite inclination, sample A was taken in the direction transverse to the slope inclination (on the upslope side). Samples were collected at the bend in the trunk. Samples from trees without visible bends were collected 1,5m above the ground. Sampling was done in the period July 10-18, 2008.

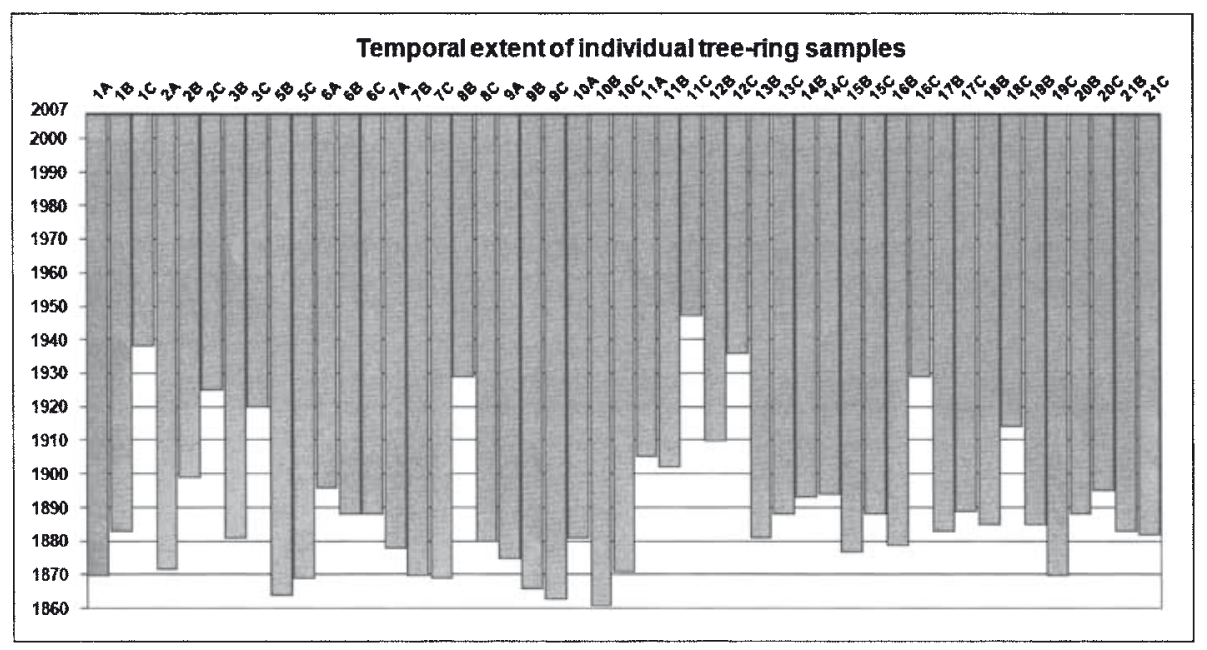

Fig. 1 Temporal extent of individual tree-ring samples

Before the proper processing, the borings were stuck on wooden strips, beveled and rubbed down in view to highlight individual tree rings. The readout of tree rings was done with the help of a TimeTable measuring device under a binocular microscope, ParSer readout module and PAST 4 program, in which growth curves were consequently modified and analyzed.

Growth curves were used to evaluate the eccentricity $\left(E_{i}\right)$ of individual tree rings for the given year $(i)$. A numerical value of eccentricity was calculated according to the formula proposed by Braam et al. (1987a) and modified for deciduous trees. The form of this formula is

$$
E_{i}=\frac{R_{C}-R_{B}}{R_{C}+R_{B}} \text { or } E_{i}=\frac{R_{B}-R_{A}}{R_{B}+R_{A}},
$$

where $E_{i}$ is the eccentricity and $R$ the width of a tree ring in the respective direction (A, $\mathrm{B}$ or $\mathrm{C}$ ). According to the degree of eccentricity, tree rings were divided into three categories: slightly eccentric (0.1-0.3), medium eccentric $(0.31-0.5)$ and strongly eccentric (more than 0.5) (Burda 2008). Space and time variability of slope movement was evaluated with the help of index of activity $I_{i}$ in the given year (Fantucci and Sorriso-Valvo 1999), i.e.: 


$$
I_{i}=\frac{\sum R_{k} i}{\sum A_{k} i} \times 100,
$$

where $R_{k, i}$ is the number of trees inclined in the year $i$ and $A_{k, i}$ is the total number of trees monitored in the year $i$. It is thus the percentage of damaged trees out of their total number.

Growth changes between individual tree rings were also assessed with the help of both growth curves and numerical expression of decrease or increase of growth in individual years. The last assessment was done according to the distribution of growth changes into three categories of the degree of growth decrease (S1 40-55\%, S2 56-70\%, S3 more than 70\%) and into three categories of growth increase (R1 50-100\%, R2 101-200\%, R3 more than 200\%) (Burda 2008). These changes were considered to be related to a geomorphic event, such as landsliding, when growth recovery or growth reduction existed during three successive years. Growth changes lasting only one or two years can be caused by other reasons, such as fluctuation of climate (Carrara and O'Neill 2003; Van Den Eeckhaut et al. 2009). For evaluation, only the B samples were used as they were not influenced by formation of reaction wood. Finally the index of activity $I_{i}$ in individual years was used again.

Further the standard curve was created in the PAST 4 program with elimination of trend from the growth curve of control trees. Double detrending was done with the help of the negative exponential function (the so-called Korf's curve) eliminating the growth trend and with the help of an 11-year running average eliminating impacts of competition (concurrence). The resulting curves were consequently averaged.

Precipitation data (monthly amounts) were available from the three nearest stations Synalov, Sejřek and Štěpánov. From the nearest station Synalov the data were available only since 1996, therefore data from the more remote station Sejřrek were used (data since 1961).

The greatest growth trend changes in trees can be expected when there are oscillations of precipitation amounts between consecutive years. With a significant increase of precipitations we can presume an increase of wood substance formation and vice versa. Therefore, we compared precipitation amounts in a vegetation period with the standard curve. The curve can then be used for evaluation of climatic events in past years, for which data are not available. This can be done when there is good correlation of individual oscillations. The elimination of growth trend and of the impact of competition from the curves of the control samples stresses the climatic signal in the standard curve.

For each sampled tree, data on its position within the failure, on its trunk morphology and its deformations were also obtained, and the diameter of the tree, the core position and information on neighboring trees were recorded (Bollschweiler 2007). Unnatural growth characteristics can be influenced by other non-geomorphologic causes, such as wind gusts, unequal moisture and nutrients distribution, irregularly developed roots or episodes of noxious insect outbreak. The majority of these causes do not result in growth of identifiable eccentric tree-rings (Braam et al. 1987b).

Data on precipitation amounts were used for comparing periods of increased slope deformation activity with the rainfall amount. The influence of precipitation was 
assessed by studying a weighted 3-year moving average. Values for individual years were evaluated using the equation:

$$
y=\frac{x_{i}+0,66 \times x_{i-1}+0,33 \times x_{i-2}}{2},
$$

where $x_{i}$ is total annual precipitation in year $i$ (Rybár 1999; Rybár 2007). Precipitation amounts from earlier periods have less relevance in the equation.

\section{Results}

Morphological characteristics of the slope deformation

On the basis of field research, surface forms (see Fig. 2-2, colour appendix) on the slope above the Běleč I portal bearing evidence of the presence of a slope failure were described.

The concerned slope in the area above the tunnel portal has the shape of a small rock ridge between two partial couloirs. On the ridge there are several terrain steps with walls formed by systems of rock outcrops. The steps both follow the directions of the primary tectonics and run across the primary structure. These forms are interpreted as walls formed by partial depressions of the slope surface. At their foot, there are tension or shear zones under the form of linear depressions also crossing areas without outcrops.

The main line of terrain steps bordered by depressions forms characteristic structures of several sliding couloirs. The morphologically most pronounced are the smallest and at the same time the lowest ones of them (Fig. 3-2, see colour appendix). Higher situated steps are then part of a significantly greater couloir reaching probably to the area of a further partial ridge situated westwards. The couloir's base is concave in crosscut with less pronounced outcrops.

Other forms related to slope movements are linearly ordered forms of slope surface deformation oriented slantly to perpendicularly to the directions of the rocky outcrops walls (Fig. 4-2, see colour appendix). In places of intersection of these lines with outcrops there are rocks deformed by movements. Outside of the outcrops, the lines appear as zones of loosening of block debris or as steps or depressions in bloc fields. These lines are however interpreted as deformations of lower orders. In addition, cross zones of secondary deformation in NNE-SSW direction correspond in two places by their position on the slope surface to two main places of damaging of the tunnel. Also, two very pronounced failures crossing the slope in the direction corresponding to that of the water tunnel, but not to the structural one, are interesting.

The forms of slope deformation of the lowest order are forms of gneiss deformation, e.g. the opening of existing cracks, formation of new cracks, crushing and breaking off of contacts of gneiss partial blocks which are not evident in outcrops in the larger neighborhood of the slope deformation.

From the point of view of recency of forms and relative size of surface forms, the concerned slope can be divided into several portions. In the lower portion of the slope there occur relatively recent but only the smallest forms. In the middle portion there are recent and large forms, whereas in the upper portion of the slope, there are large forms which do not seem so recent. 


\section{Tree ring analysis}

The dynamics of slope movements in the area of interest was at first assessed for the whole slope above the tunnel's portal, i.e. for all trees.

Fig. 5 shows that index $I_{i}$ does not reach higher levels, i.e. movements do not occur in all portions of the slope at the same time. Therefore the level of eccentricity was assessed separately for trees growing within the delimitation of the slope failure from geomorphological mapping.

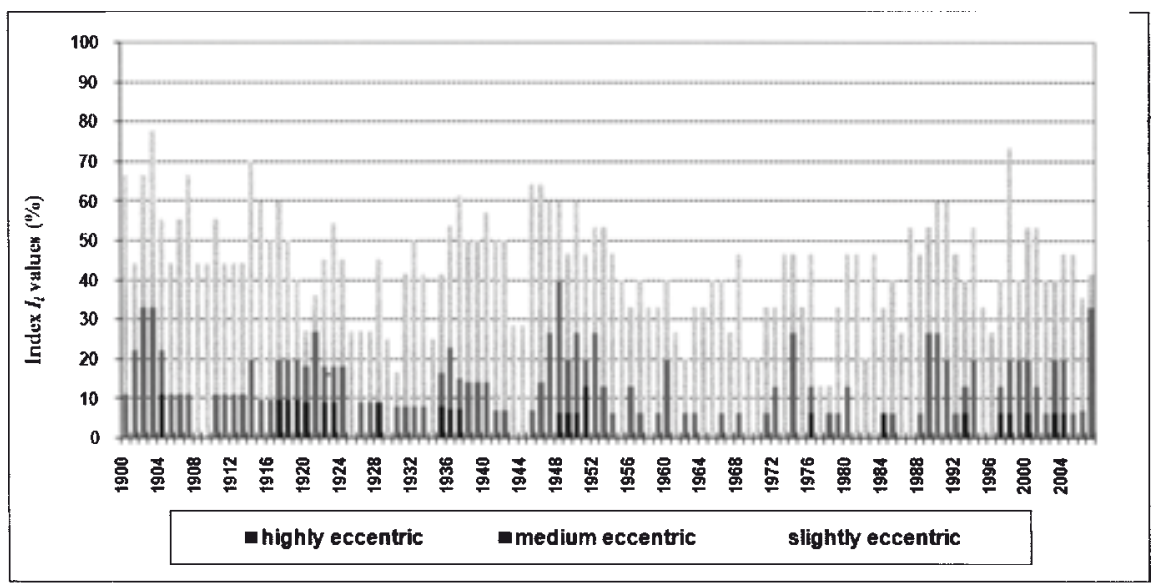

Fig. $5 I_{i}$ values according to the degree of tree ring eccentricity for the whole analysed area

Fig. 6 shows that within the slope deformation, movements in its whole profile cannot be presumed. They are rather movements differentiated into partial portions of the slope. Nevertheless, according to the calculated values several periods of increased movement activity can be determined, i.e. in the years 1915, 1944, 1947, 1975, 1987, 1993, 1997 and 2002.

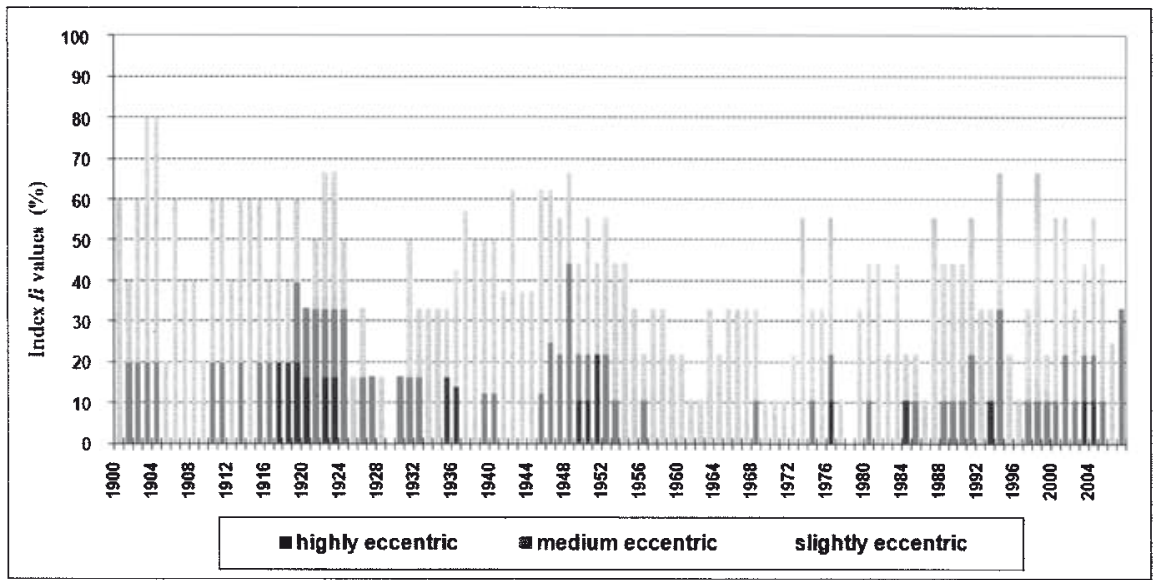

Fig. $6 I_{i}$ values according to the degree of tree ring eccentricity for the presumed delimitation of the slope deformation 
A better space interpretation needed to be done by analyzing the levels of eccentricity in individual trees and their groups according to their localization on the slope. The first group is formed by trees $\mathrm{N}^{\circ} 1,3,5,12$ and 13 situated in the lowest portion of the slope, where there are the most recent forms and where the highest activity is presumed. Curves displaying eccentricity have an uneven course with many oscillations. Growth disturbances are relatively frequent. A significant peak is reached by all curves in the year 1948; this peak (shows a reaction to some event in 1947) is most significantly manifested in trees 1 and 3 . As this peak is concordant in all curves, it can be presumed that it is not only a product of phototropic reaction due to competition, but also that inclination was initiated by a slope movement which could have occurred in the whole profile of the deformation.

Another group includes trees 6 and 7, situated in the upper portion of the slope below the edge of the presumed slope failure. Here, we presume movements along shear planes. They could have caused inclination of trees in this portion in the opposite direction. Therefore A samples were also taken and analyzed. Eccentricity levels of trees calculated for this direction were not significantly concordant. Although levels, mainly in tree 6 , reached in certain years relatively high values, it cannot be presumed that inclination was caused by slope movement. The situation is similar when assessing inclination in the opposite direction, where curves do not manifest concordance in more significant peaks. The only common year, when disturbances were registered, was the year 1948, but there are only medium eccentric tree rings. It can be assumed based on these findings that a part of the failure in the upper portion is already stabilized and no significant movements occur there. Unfortunately, only two trees were found and analyzed in this segment, which is insufficient for assessment from which reliable conclusions can be made.

In the middle portion of the slope, trees 9, 10 and 11 were analyzed; they are situated below rock outcrops representing assumed surface outcrops of shear areas. For this reason, A samples were taken, too. When evaluating inclination in the direction against the slope, one period with identical eccentricity was found. It is the period 1964-1966. In this period (with above-average rainfall) all curves are identical. Disturbance in 1963 could thus have been caused by inclination of trees in accordance with movement on the shear area. As these disturbances were not registered in the other portions of the slope, this is probably only a local movement. As these are not very significant levels of eccentricity, the mentioned movement was probably only small. Inclination of trees in the opposite direction, i.e. down the slope, was registered to a higher degree only in tree 10, where an increased eccentricity has been evident approximately since 1983. In this case it is probably only a phototropic reaction (according to the situation in the site).

In the remaining trees $14,15,16,18,19$ and 20 inclined down the slope, formation of eccentric tree rings was assessed. The trees are situated without the presumed mapped extent of the slope failure in places without more significant surface forms witnessing large scale movements. Nevertheless, the trees manifest macroscopic signs of inclination and were studied in order to determine the slope stability also in these places. 


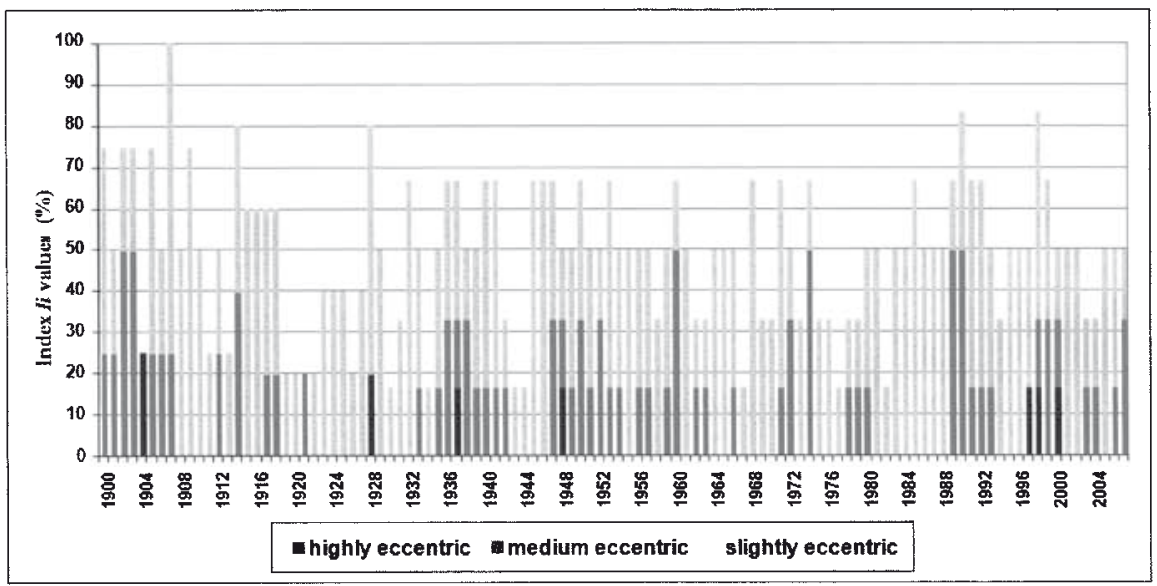

Fig. $7 I_{i}$ values according to the degree of tree ring eccentricity of trees situated on the slope in the neighbourhood of the slope deformation

The graph in Fig. 7 does not display significant maxima; the levels are, differently from those for the trees directly on the failure, distributed relatively evenly for the whole studied period. Periods of a slightly increased formation of eccentric tree rings evoke events in the years 1935, 1947, 1959, 1973, 1988 and 1997. These periods (with the exception of the years 1947 and 1997) do not correspond to similarly delimited periods within the slope failure. It can thus be presumed that the portion of the slope further to the SW is not included in the slope deformation area of interest. Nevertheless, in order to compare the eccentricity level for individual trees in this area, the slope is affected at least by movements of shear character affecting probably only slope accumulations. This is proved by an increased degree of eccentricity in the periods 1936-1941 and 1948-1950 manifested accordingly in trees 14, 16, 18 and 20. In compliance with relief morphology and localization of these trees, it is possible that in the given years movements got quicker and a smaller slope movement of stream character developed there.

\section{Analysis of sudden growth changes}

Consequent sudden growth changes corresponding to changes of the site conditions were assessed. They could also have been caused by climatic oscillations, so that time duration of growth changes were also evaluated.

Abrupt growth changes of certain trees on the slope failure were registered in some cases in other years than in trees in the neighborhood of the failure. It can be also deduced that some changes result from geomorphic events. Increased levels of $I_{i}$ index in trees on the slope deformation, which indicated enhanced growth, were observed in the years 1921, 1935, 1947, 1963, 1975, 1983, 1997, 2006 and 2007. From these, only the years 1947, 1975, 1997 a 2006 correlate with years of increased formation of eccentric tree 
rings. They occur maximally in $50 \%$ of cases, so that it is not possible to affirm that in individual years there were movements in the whole area of the deformation.

Research on tree rings of trees on the slope failure manifesting in the given year a suppression growth makes it clear that they grew less frequently than in the previous case. The highest levels of $I_{i}$ index were registered only in the years 1997, and 2006. These years correspond to the results of the analysis of eccentric tree rings and with periods of above-average amount of rainfall.

Table 1 Table summarizing all main findings. The years with activity of slope deformation reflecting growth change in trees

\begin{tabular}{|l|l|}
\hline EXCCENTRIC TREE-RINGS & \\
\hline deformation & $1915,1944, \mathbf{1 9 4 7}, 1975,1987,1993, \mathbf{1 9 9 7 , 2 0 0 2}$ \\
\hline group 1 & $\mathbf{1 9 4 7 , 1 9 9 3}$ \\
\hline group 2 & 1923,1947 \\
\hline group 3 & 2002 \\
\hline neigbouring slope & $1935, \mathbf{1 9 4 7}, 1959,1973,1988, \mathbf{1 9 9 7}$ \\
\hline SUDDEN GROWTH CHANGES - abrupt growth & \\
\hline deformation & $1921,1935,1947,1963,1975,1983,1993$ \\
\hline group 1 & $1921,1947,1975$ \\
\hline group 2 & 1923,1993 \\
\hline group 3 & $1963,1967,1973,1983$ \\
\hline neigbouring slope & $1922, \mathbf{1 9 5 0}, 1959,1973,1975,1983$ \\
\hline $\begin{array}{l}\text { SUDDEN GROWTH CHANGES - suppression } \\
\text { growth }\end{array}$ & \\
\hline deformation & $\mathbf{1 9 9 7 , 2 0 0 6}$ \\
\hline group 1 & 2006 \\
\hline group 2 & 1997 \\
\hline group 3 & $\mathbf{1 9 9 7 , 2 0 0 6}$ \\
\hline neigbouring slope & 1997 \\
\hline $\begin{array}{l}\text { group 1: trees 1, 3, 5, 12, 13 - lower part of deformation, group 2: trees 6, 7 - upper part, group 3: 9, } \\
\text { 10, 11 - middle part }\end{array}$ \\
\hline
\end{tabular}

\section{Comparison of periods of increased slope deformation with rainfall data}

The influence of precipitation on the activity of slope deformation was assessed by a weighted 3-years moving average of annual precipitation. Figure 8 shows a significant 
increase of slope deformation in 1997, 2002 and 2006, when an above-average precipitation amount was registered. Nevertheless, there is no significant correlation between moving average and data from tree-ring analysis indicating movements in 1974. There is correlation rather between obtained data and total annual precipitation. This indicates a rather shallow flow movement rather than deep-seated movements. Unfortunately, quantifying of the deformation rate was impossible from the dendrogeomorphological analysis, so that an exact comparison of deformation activity with the rainfall data was not assessed. Nevertheless, peaks on the curve agree with periods of increased slope movement activity (Fig. 8). However, there is better correspondence for values of total annual precipitation than for moving averages.

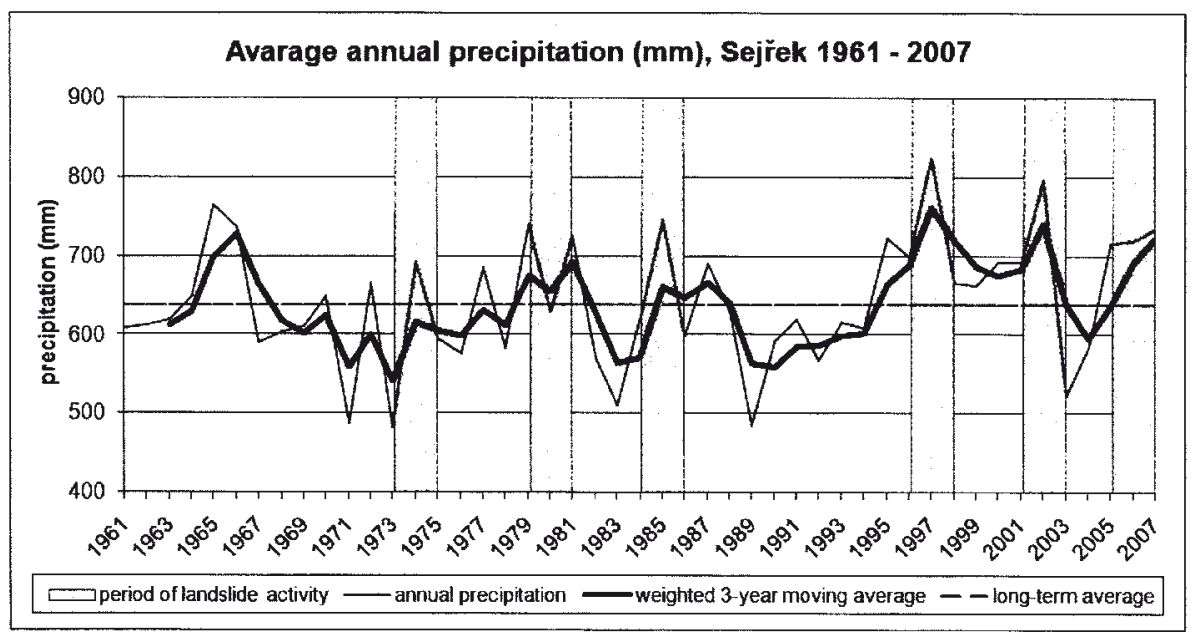

Fig. 8 Comparison of periods of increased slope deformation with rainfall data Source of precipitation data: ČHMÚ

\section{Discussion and conclusions}

The problem of the present activity of the slope deformation was assessed by dendrogeomorphologic analysis, the potential of which for ascertaining slope movements dynamics was recently verified by several authors, such as Stoffel (2006), Perret et al. (2006), Bollschweiler et al. (2007) or Tamulonis and Kappel (2009). It follows from the results of this analysis that the slope failure does not manifest signs of a greater activity in its whole extent, but that there occur local, rather episodic, movements, creep and loosening of the near-surface zone of the gneiss massif. From this viewpoint, no continuous movements along shear planes were proven, nevertheless creeping movements in the order of tens of $\mathrm{mm} / \mathrm{year}$ cannot be excluded. The occurrence of shear planes was verified both by mapping of landforms on the failure and by geophysical research (P. Dostál, oral communication) and it is therefore probable that in the past, movements used to occur along these surfaces. Past movements of deformation over its whole extent are also proved by the measuring of 
crack systems on the slope done by Hanžl a Buriánek (2005). A rose diagram of crack orientation on the slope manifests two significantly prevailing directions. In the case of chaotic movement of blocs, it can be assumed that the measured values would be dispersed in more directions. The measured values thus confirm the hypothesis of movements of the whole deformation at the same time.

At present, however, movements along the shear planes' seam have already calmed (the separating edge is not well evident any more). It is also confirmed by the results of the dendrogeomorphological analysis. But we must take into consideration that only a limited number of samples from the upper portion of the slope were available and the results could therefore be distorted.

The activity of the deformation is more pronounced in the middle and mainly in the lower portion of the failure, where probably local episodic slope movements occur, (especially in a period of above-average precipitation amount). Dendrogeomorphological analysis helped to ascertain that movements of a larger extent could have occurred in 1947 and 1997. Nevertheless, there are no reports or records on movements in these years in the local archives. Thus, during the whole observed period they were rather only movements of local character, i.e. creep and block loosening of the near-surface slope zone. Movements are also evidenced by deformation zones found during mapping of the slope deformation within the research. However, local movements on the neighboring slope were determined from the dendrogeomorphological analysis.

The gathered information also enables the evaluation of two variants of impact of the deformation on the tunnel damage in 2005. Zvelebil et al. (2006) prefer the impact of a deep-seated failure of creeping character moving along shear surfaces reaching the tunnel's body. On the contrary Pavlík (2005) prefers possible discharge of the massif due to movement of blocks in the near-surface zone. As it ensues from the results of this paper, it is probable that both variants played their part during the failure development. It is nevertheless probable that neither of them was the direct cause of the breakdown. This affirmation is proved by the fact that at the time of damaging of the tunnel there were no significant movements of either of the two types registered on the slope. Against the first variant is also the difference in orientation of cracks in the tunnel's body and in the course of shear planes (Pavlík 2005). From this point of view and on the basis of our research, we prefer the hypothesis by Pavlík (2005), i.e. that the breakdown was caused by several adverse factors occurring at the same time.

The impact of non-geological causes cannot be assessed on the basis of this paper. It is nevertheless probable that geological causes participated in the breakdown under the form of worsened geomechanical qualities of rocks above the tunnel due to the presence of neotectonical fault zones and also due to further deterioration of rocks of the massif by slope movements of both mentioned types. This predisposition to failure probably appeared in the past even before the construction of the tunnel conduit.

Because of the low number of samples processed by dendrogeomorphological analysis and because of their uneven distribution on the slope (insufficient number of suitable trees) it would nevertheless be advisable to verify the present activity by further research. Control monitoring of the slope by precise devices measuring movements appears to be a suitable solution. This procedure was already proposed by the Czech Geological Survey (Zvelebil et al. 2006), which recommended monitoring 
the slope by methods of precise dilatometric measuring. This measuring has not yet begun. Another possibility is to use the extensometric profile installed by the firm Geotest Brno on the slope above the Běleč portal, where, up to now, only basic measuring was done in 2005 (Pavlík 2005). If this profile is used, it will be require additional modifications in order to obtain reliable results.

Dendrogeomorphology is a method offering a view on the recent slope movement activity (roughly 100 years). Possibilities of further dating of the slope deformation by other methods, used for instance by Baroň (2007) or Hradecký and Pánek (2004), such as palynologic analysis or radiometric dating, do not seem suitable for this locality. We cannot presume finding of suitable materials for such analyses; they are usually buried under accumulations or situated in frontal depressions. For assessing the dynamics of near-surface slope movements and of loosening of the massif in the near-surface part, lichenometric analysis (Innes 1985) could be helpful.

Any movements which could have caused the breakdown of the water-supply conduit were not registered. Local movements, such as creep and loosening of the nearsurface zone of the gneiss massif, occur episodically, especially in years with an aboveaverage precipitation amount. These movements occur on the slope with evidence of the older deep-seated movement, which has already calmed, as well as on the neighboring steep slope with no evidence of earlier deep-seated movements, where there are no symptoms of older movements. Results of the study showed that the described movements were not the direct cause of the conduit breakdown.

\section{Acknowledgement}

The authors would like to thank the Ministry of Education, Youth and Sports of the Czech Republic (Projects MSM 0021620831) for the financial support.

\section{References}

ALESTALO, J. (1971): Dendrochronological interpretation of geomorphic processes. Soc. Geogr. Fenn., Fennia 105, pp. 1-140.

BAROŇ, I. (2007): Results of radiocarbon dating of deep-seated landslides in the area of Vsetín and FrýdekMístek districts (in Czech, English summ.). Geol. Výzk. Mor. Slez. V roce 2006, pp. 10-12

BOLLSCHWEILER, M. ET AL. (2007): Reconstructing spatio-temporal patterns of debris-flow activity using dendrogeomorphological methods. Geomorphology 87, pp. 337-351.

BRAAM, R. R. ET AL. (1987a): Spatial and temporal analysis of mass movement using dendrochronology, Catena, vol. 14, pp. 573-584

BRAAM, R. R. ET AL. (1987b): Dendrogeomorphological analysis of mass movement a technical note on the research method. Catena, vol. 14, pp. 585-589

BURDA, J. (2008): Assessment of recent mass movements dynamism in the area of Jezeři (in Czech, English summ.). graduation thesis, Praha, Prrf UK, 107 p.

CARRARA, P. E., O'NEILL, J. M. (2003): Tree-ring dated landslide movements and their relationship to seismic events in southwestern Montana. Quaternary Research, 59, pp. 25-35.

CIGLER, Z., FOLLPRECHT, J. (2007): Vír regional water supply - sanitation of concrete lining of the fresh water supply conduit Švařec - Běleč I. and Běleč II. - Štěpánovice (In Czech). Proceedings of $12^{\text {th }}$ International Seminary: Reinforcement, sealing and anchoring of rock massive and building structures 2009. VŠB- TU Ostrava, pp. 72-80. 
DAŇHELKA, J. (1999): Dendrogeomorfological research of landslide next to Čeřeniště, Ústi nad Labem region (in Czech, English summ.). Graduation thesis, Praha, Přf UK, 94 p.

DEMEK, J., MACKOVČIN, P. (2006): Geographical lexicon of the Czech Republic: Mountains and lowlands (in Czech). Brno, AOPK ČR, 582 p.

FANTUCCI, R., SORRISO-VALVO, M. (1999): Dendrogeomorphological analysis of a slope near Lago, Calabria (Italy). Geomorphology 30, pp. 65-174.

GÄRTNER, H. ET AL. (2003): Tree ring analyses and detailed geomorphological mapping on a forested debris flow cone in Switzerland. In: Rickenmann, D. Chen, C. (eds.): Debris flow hazards mitigation: mechanics, prediction, and assessment. Proceedings of the Third International Conference on DebrisFlow Hazards Mitigation. Rotterdam, Millpress, pp. 207-217.

HANŽL, P., BURIÁNEK, V. (2006): Characterization of crack systems of the south east slope in the Křeptovský brook valley above the Vír water supply (In Czech). In: Zvelebil, J., Krejčí, O., et al. (2006): Assessment of the landslide area next to the portal of VOV Běleč I. Unpublished report. Praha, Brno, Czech geological survey, $2 \mathrm{p}$.

HEINRICH, I., GÄRTNER, H. (2008): Variation in tension wood of two broad-leaved tree species in response to different mechanical treatments: Implications for dendrochronology and mass movement studies. International Journal of Plant Sciences, 169, 7, pp. 928-936.

HOLLAND, R., ET AL. (2008): Spatiotemporal reconstruction of a landslide in the Swabian Alb (Southwest Germany) - A dendrogeomorphological approach. In: European Geoscience Union (Eds.): Abstracts IV. General Assembly, Vienna (Austria)

HRADECKÝ, J., PÁNEK, T. (2004): Contribution to the chronology of the slope deformations in the Jablunkov Furrow and the Slezské Beskydy Mts. (in Czech, English summ.). Geol. Výzk. Mor. Slez. 2003, pp. 88-90.

INNES, J. L. (1985): Lichenometry. Progress in Physical Geography, 9, pp. 187-254.

PAOLINI, L., VILLALBA, R., GRAU, H. R. (2005): Precipitation variability and landslide occurrence in a subtropical mountain ecosystem of NW Argentina. Dendrochronologia, 22, pp. 175-180.

PAVLÍK, J. (2005): Final report on the geotechnical research of the broken part of the Vír water supply conduit Běleč I. Unpublished report. Brno, Geotest Brno, a.s., 13 p.

PERRET, S. ET AL. (2006): Spatial and temporal rockfall activity in a forest stand in the Swiss Prealps A dendrogeomorphological case study. Geomorphology 74, pp. 219-231.

ROŠTÍNSKÝ, P., KIRCHNER, K. (2006): Block-type slope in crystalline in the Svratka river valley, northwest from Tišnov (in Czech, English summ.). Geografie-Sborník ČGS 111, 2, pp. 217-220.

RYBÁ ̌́, J. (1999): Climatic effects in the development of landslides and other dangerous slope movements (in Czech, English summ.). In: Barvínek, R. et al. (eds.): Quido Záruba 1899-1993 zakladatel československé inženýrské geologie. Geotechnické dny Praha 1999 - Sborník přednášek: Sesuvy a inženýrskogeologické poměry Prahy. Informační centrum ČKAIT, Praha, 56 p.

RYBÁR̆, J. (2007): Climatic effects in the development of different types of slope movements (in Czech, English summ.). Zprávy o geologických výzkumech v roce 2006, Praha, ČGS, pp. 90-92.

SHRODER, J. F. (1980): Dendrogeomorphology, review and new techniques of tree-ring dating. Progress in Physical Geography 4, 161-188.

STOFFEL, M. (2006): A Review of Studies Dealing with Tree Rings and Rockfall Activity: The Role of Dendrogeomorphology in Natural Hazard Research. Natural Hazards 39, pp. 51-70.

TAMULONIS, K. L., KAPPEL, W. M. (2009): Dendrogeomorphic assessment of the Rattlesnake Gulf landslide in the Tully Valley, Onondaga County, New York: U.S. Geological Survey Scientific Investigations Report 2009, 5134, 14 p.

VAN DEN EECKHAUT, M. ET AL. (2009): Evidence for repeated re-activation of old landslides under forest. Earth Surface Processes and Landforms, 34, pp. 352-365

VESELÝ, I. (1983): Final report on detailed engineering geological research for a purification plant in papermanufactory in Prudká (in Czech), Brno, Geotest Brno, a.s., pp. 2-6

ZVELEBIL, J., KREJČÍ, O., ET AL. (2006): Assessment of the landslide area near the portal VOV Běleč I. Unpublished report. Praha, Brno, ČGS, 10 p. 


\section{Résumé}

Využití dendrogeomorfologických metod při výzkumu svahové deformace Běleč, Českomoravská vrchovina (Česká republika)

Výzkum hluboce založené plouživé svahové deformace Běleč je příspěvkem k identifikaci př́ǐin vzniku poruchy vodovodního přivaděče Brněnských oblastních vodovodů a zajištění jeho provozu.

Při výzkumu poruchy bylo využito geomorfologického mapování a dendrogeomorfologických metod (analýza excentrických letokruhů, růstové změny), které sloužily ke studiu dynamiky svahové poruchy. Aktivita svahových pohybů mezi roky 1900-2007 byla zkoumána pomocí 45 vyvrtaných jádrových vzorků. Analýza letokruhů buku lesního (Fagus sylvatica) neprokázala kontinuální pohyby v celém rozsahu deformace. Současná aktivita je charakteristická spíše lokálními epizodickými pohyby plouživého charakteru v letech 1947, 1975, 1993, 1997 a 2002. Bylo tak prokázáno, že svahová deformace neměla přímý vliv na poruchu vodovodního přivaděče $\mathrm{v}$ roce 2005 .

Daniel Žižala Research Institute for Soil and Water Conservation Prague

Žabovřeská 250 15627 Prague 5 - Zbraslav

Czech Republic tel.: +420257027211 e-mail:dzizala@vumop.cz

Jiři Zvelebil

Charles University in Prague, Faculty of Science Department of Physical Geography and Geoecology

Albertov 6

12843 Praha 2

Czech Republic tel.: +420602259951 e-mail: zvelebilj@seznam.cz

Vit Vilimek

Charles University in Prague, Faculty of Science Department of Physical Geography and Geoecology

Albertov 6

12843 Praha 2

Czech Republic tel.: +420221951361 e-mail:vilimek@natur.cuni.cz 


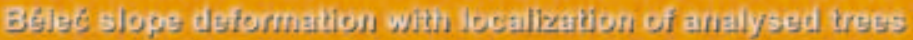
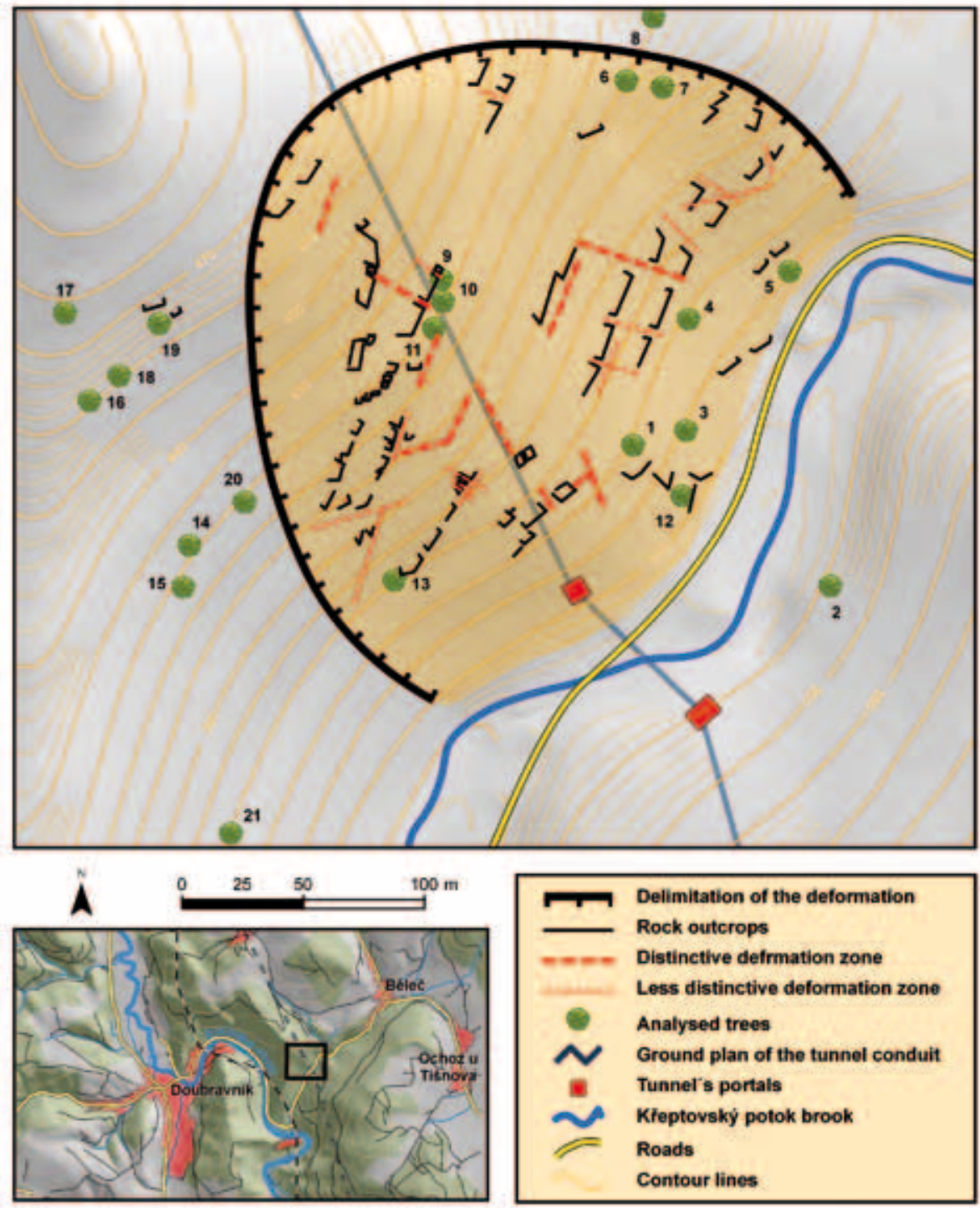

\begin{tabular}{|l|} 
Relimitation of the deformation \\
Ristinctive defrmation zone \\
Less distinctive deformation zone \\
Analysed trees \\
Ground plan of the tunnel conduit \\
Tunnel's portals \\
Kfeptovsky potok brook \\
Roads \\
Contour lines
\end{tabular}

Fig. 2-2 The area of the Běleč slope deformation with localization of analysed trees 


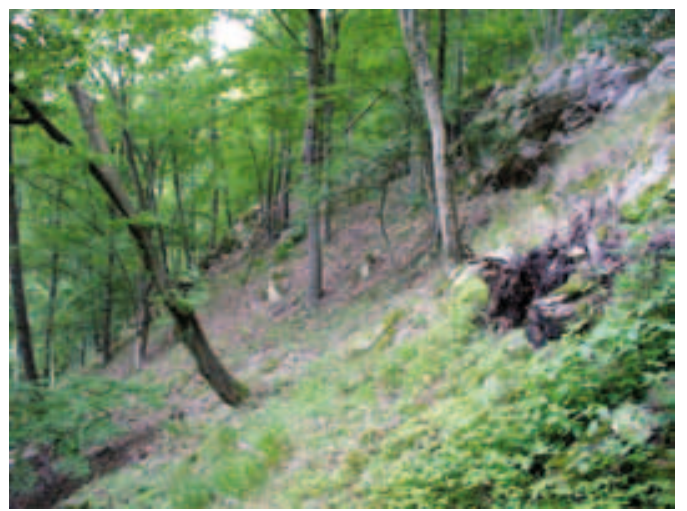

Fig. 3-2 Landslide cirque in the lower portion of the slope

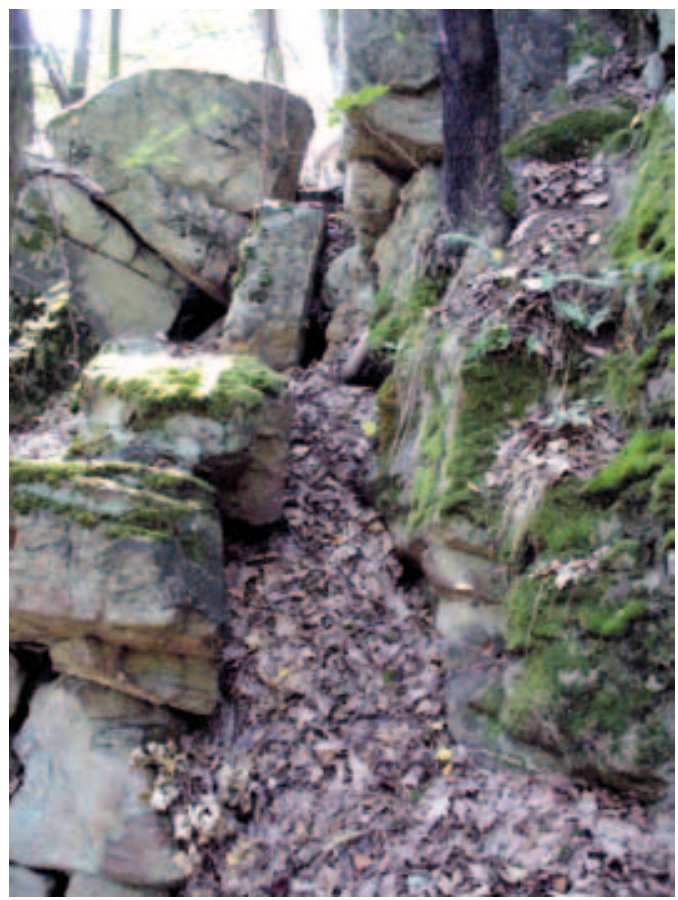

Fig. 4-2 Linear deformation running across a rock outcrop 